\title{
Cartografias políticas Atlas de Ana Borralho e João Galante
}

Francesca Rayner

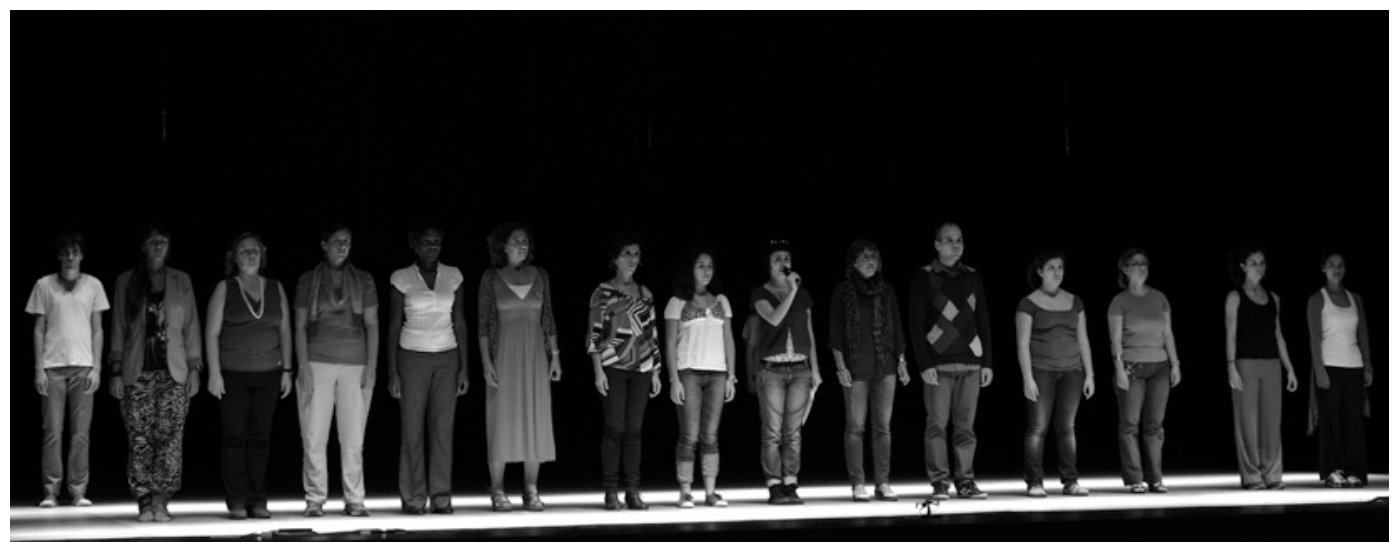

de Ana Borral ho

e João Galante,

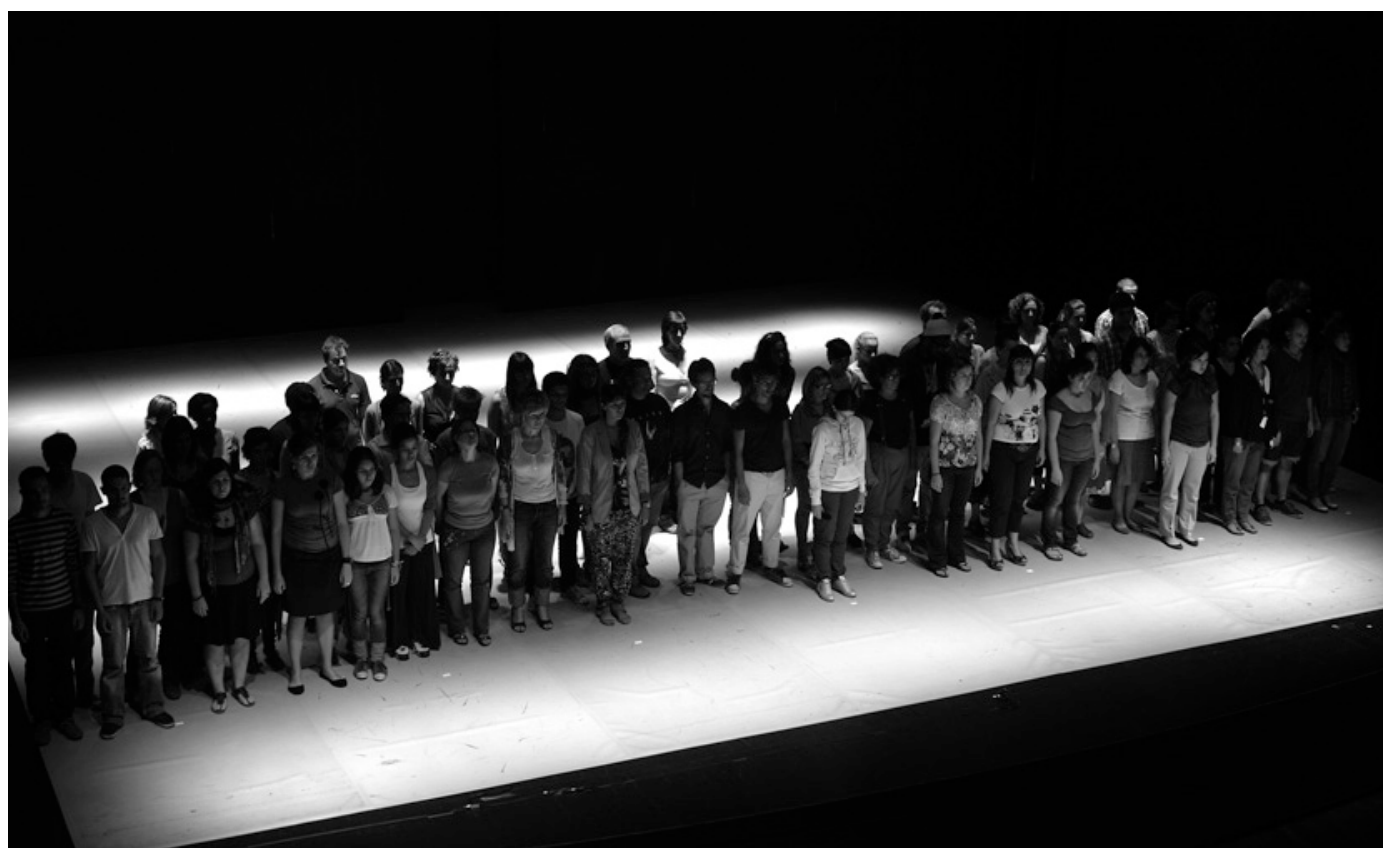

Título: Atlas. Conceito e direcção artística: Ana Borralho e João Galante. Luz: Ana Borralho e João Galante. Aconselhamento de luz: Thomas Walgrave. Som: Colgate. Colaboração dramatúrgica: Fernando Ribeiro \&t Rui Catalão. Colaboradores artísticos e coordenadores de grupos: Catarina Gonçalves, Carla Leitão (Alface), Marie Mignot e Tiago Gandra. Video: Helena Inverno e Verónica Castro. Fotografia: Vasco Célio. Produção executiva: Ana Borralho e Mónica Samões. Performers: 100 pessoas de diferentes profissões. Local e data de estreia: Teatro Municipal Maria Matos, Lisboa, 22 de Outubro de 2011. 
Há hoje em Portugal muitas pessoas que estão verdadeiramente zangadas, mas a quem falta acesso a um lugar público e capacidade de intervenção para poderem exprimir os seus sentimentos. Se o teatro há-de ter algum papel importante neste tempo de "não há alternativa" e "a pobreza há-de tornar-te mais rico", é enquanto fórum para legitimar essas vozes, que de momento não estão a ser escutadas, e para a presença desses corpos naquele que é o corpo político, mas que os políticos e os meios de comunicação de massa vêm declarando que não existem.

0 Teatro Municipal Maria Matos em Lisboa está bem colocado para funcionar justamente como um fórum deste tipo. Desde que assumiu o cargo de Director Artístico, Mark Deputter tem tentado, de forma consistente, abrir o teatro à comunidade, favorecendo o acesso a esse palco por parte de artistas de teatro portugueses como é o caso de Ana Borralho e João Galante, responsáveis por este espectáculo. A programação por temas, que encontram eco entre artistas e público, é exemplar na sua coerência: sobre a abundância, na temporada anterior, e, agora, sobre a pertença. Tal como aconteceu com estes espectáculos que celebravam o 42. ${ }^{\circ}$ aniversário deste teatro, ocasiões houve em que a celebração não deixou de integrar a crítica social.

É visível uma diferença logo no foyer, antes mesmo de se iniciar o espectáculo. Para começar, o teatro está cheio. Depois, enquanto a maior parte dos públicos de teatro de hoje são jovens brancos e da classe média, ali havia muitos rostos escuros, corpos mais velhos, trabalhadores de profissão, que olham à volta, ligeiramente nervosos, sem saberem exactamente o que esperar, mas interessados em vir e em apoiar a família e os amigos. Tem havido recentemente algumas queixas, não despiciendas de resto, relativamente ao facto de se instrumentalizar o teatro para abordar problemas sociais e económicos pelos quais o teatro não é, a bem dizer, responsável, mas neste caso tanto artistas como espectadores usaram a ocasião para desafiar mais do que para consolidar o que tem sido o status quo.

Atlas foi, sem qualquer dúvida, o melhor espectáculo que vi este ano, pelo seu claro humanismo e pela ideia de que quando se oferece um lugar para as pessoas fazerem ouvir a sua voz, é isso mesmo que elas fazem. A premissa estabelecida por Ana Borralho e João Galante era claríssima: tragam cem pessoas de profissões diferentes e deixem que se apresentem a si próprias em palco. Contudo, a frase com a qual todas estas pessoas se apresentaram tornou este espectáculo não apenas uma experiência teatral interessante - ao levar à cena vidas vulgares -, mas também uma intervenção social importante. "Se um (/dois/três) pastor (técnico de contas/psicóloga) incomoda muita gente, dois (três/quatro) pastores (técnicos de contas/psicólogas) incomodam muito mais", sendo a segunda parte dita em coro por todos os que estavam no palco. Esta frase simples evocava tanto o poder do testemunho individual, como o poder político potencial do colectivo. 0 momento que melhor ilustrou este potencial foi, mais ou menos a meio do espectáculo, quando um homem se dirigiu à zona central do palco dizendo: "Se quarenta desempregados incomodam muita gente... 555.000 incomodam muito mais" e, de imediato, a ele se juntou a voz dos que estavam no palco e o aplauso do público.

Durante o resto do espectáculo, os actores individuais introduziam pequenos pormenores que tornavam a sua frase diferente da dos outros. lam desde uma mãe com quatro filhos, "nenhum deles baptizado, nenhum deles vacinado", à actriz "intermitente" que tinha acumulado um cem número de outros trabalhos, todos a recibo verde. Deram voz a "uma funcionária pública que trabalha num Museu Nacional e que ainda pensa que "a cultura vale a pena", assim como à "artista plástica alucinada" e ao "técnico de seguros reformado antes do tempo (e com uma grande penalização, por isso mesmo)". No final do espectáculo uma jovem veio ao proscénio e começou a frase "se cem pessoas incomodam muita gente ...", deixando a segunda parte da frase em suspenso. A mensagem era clara: cem pessoas juntas não são apenas presença, são também poder.

Foi muitíssimo comovente ver como as pessoas se mostravam orgulhosas com as suas mais variadas profissões. 0 pormenor com que se anunciavam nas suas profissões muito especificas - como, por exemplo, secretária reformada, antiga "teletipista" - revelava não apenas a natureza restritiva das definições que o Estado confere aos empregos, mas também o sentido e o valor 
que as pessoas atribuiam ao trabalho que realizavam. Este sentimento de orgulho está hoje ferido de morte pelo clima que se criou e em que parece que ter um emprego é em si mesmo uma recompensa.

Foi interessante verificar as muitas variações que os actores - e quem os dirigia - conseguiram introduzir no espectáculo. Afinal, cem pessoas a anunciarem simplesmente o que faziam para ganhar a vida poderia parecer uma base pouco promissora para um espectáculo. Contudo, as apresentações em palco produziam um curioso efeito de acumulação que fazia crescer a expectativa relativamente a uma próxima declaração: um exercício para adivinharmos a profissão que teria a pessoa que vinha a seguir, antes de ela a declarar publicamente, e depois o exercício de medirmos essa revelação de encontro a preconceitos que nos levavam a conclusões baseadas fundamentalmente no aspecto exterior da pessoa. Uma senhora fina que se apresentou quase no fim do espectáculo, por exemplo, chocou o público quando começou a dizer "se setenta e duas prostitutas incomodam muita gente..." As profissões das pessoas - ou a falta delas - costumavam ser um cartão-de-visita social num tempo em que os empregos não eram assim tão poucos, mas tornaram-se hoje uma linha de fractura em que se jogam importantes lutas sociais e políticas. Como tal, elas são também um assunto candente para um espectáculo de teatro, em especial num contexto em que os trabalhadores do espectáculo estão, eles próprios, sujeitos a uma degradação semelhante no seu estatuto profissional.

Por entre as apresentações individuais, havia alguns momentos de silêncio algo sinistro, quebrado apenas pelo som de frases anónimas por parte da produção e pelo ruído de máquinas de dinheiro, bem como uma orgia ensurdecedora de barulho em que durante alguns instantes todos tentavam sobrepor a sua voz às dos outros. Não era claro o que diziam (embora tivesse havido um curto monólogo fabuloso no final), mas enquanto espaço livre em que as pessoas podiam gritar ou sussurrar o que thes ia no pensamento, aqueles poucos minutos pareciam ser de genuína libertação tanto para os actores como para o público.

No final do espectáculo, os actores desciam do palco para a sala, anulando a quarta parede, de modo a sugerirem novos formatos de comunidade e da sua relação com 0 teatro. É tremendamente importante que seja ainda possivel irmos ao teatro e sermos invadidos por sentimentos como a compaixão e a raiva ao mesmo tempo. Alguns espectadores pareciam pensar que não era aquilo o que o teatro devia fazer. Contudo, para mim este espectáculo era exactamente o que o teatro devia estar a fazer agora, ou seja, a contrapor o poder das pessoas comuns e do teatro às forças que querem que acreditemos que nada disso interessa. Construir, afinal, um atlas histórico e geográfico da sociedade humana num momento particular como uma forma de lutar por um futuro sustentado. 